\title{
Haram, masala og brede fælge En komparativ analyse af journalistiske fortællinger om minoriteters identitet
}

„Er det muligt at ændre et liv ved at fortælle det?“ (Jan Kjærstad: „Erobreren“)

\section{AF DAVID JACOBSEN TURNER}

Fortællingen er allestedsnærværende i menneskelig identitetsdannelse og i journalistisk praksis. Journalistiske historiefortællere konstruerer dagligt fortællinger om grupper af mennesker og tildeler dem dermed en given identitet. Dette er særdeles relevant i forbindelse med etniske minoriteter. To nichetidsskrifter har de senere år været forum for originale journalistiske fortællinger om minoriteternes identitet i Danmark: Kulturmagasinet „Djembe“ og Mads Brüggers indvandrerblad „Döner Magazine“. I denne artikel viser en komparativ analyse af de to magasiner to vidt forskellige narrative strategier, som journalister kan forfølge, når de italesætter - og dermed skaber - en særegen indvandreridentitet.

Fortællingen er et kernebegreb i såvel journalistikken som det moderne menneskes identitetsdannelse. Den grundlæggende modernitetserfaring: At de store fortællinger - tradition, tro, slægt osv. - er brudt sammen, efterlader det moderne menneske med et rigt udbud af identiteter. Og i forsøget på at skabe identitet, sammenhæng og mening er fortællingen uomgængelig. Narrativitetstænkerne har påpeget, at vores navigation i tid, vores sproglige erkendelse, vores selvbillede og vores konstruktion af fællesskaber og forskelle alle beror på fortællinger. Ifølge denne 
tankegang må det moderne menneske fortælle sig selv, og vi skaber os selv og hinanden i sproget.

Accepteres narrativitetstænkernes grundlæggende præmisser står det klart, at journalistiske historiefortællere besidder en væsentlig magt. En magt til at stigmatisere og trække skillelinier, men også en magt til at skabe narrativ oprejsning, en mulighed for at imødegå negative fortællinger med positive „modfortællinger“. I tilfældet etniske minoriteter beskyldes pressen netop for at skabe og understøtte negative grundfortællinger. Teorierne om narrativ oprejsning og modfortællinger er derfor særdeles relevante i denne sammenhæng.

I de senere år er der med mellemrum dukket nye livsstilsmagasiner op, som på hver deres måde forholder sig til den multikulturelle virkelighed. Men hvordan italesætter journalisterne indvandrerkulturen i disse? Hvilke eksempler på modfortællinger og narrative konstruktioner af en særlig minoritetskultur repræsenteres i magasinerne? Det er emnet i nærværende artikel. Særligt to nichemagasiner har gjort sig bemærket ved en original tilgang til emnet integration og etniske minoriteter; kulturmagasinet Djembe og Mads Brüggers indvandrerblad „Döner Magazine“. Gennem en komparativ analyse af disse vil jeg anskueliggøre nogle af de narrative strategier, en journalist kan følge, når indvandrerkulturen skal italesættes.

\section{Forskningsoversigt}

En grundpræmis i den narratologiske tænkning er, at den menneskelige begrebsverden er bygget op omkring fortællinger. „Livet selv eksisterer ikke som psykisk realitet hinsides fortællingen, “ har Jerome Bruner formuleret det (Bruner: 1987). Fortællingen opstår, hvor som helst vi kan iagttage en begyndelse, en midte og en slutning. Den franske filosof Paul Riceour har i værket „Tid og Fortælling“ argumenteret for, at selve vores navigation i tid er afhængigt af fortællinger, idet vi først kan begribe historien og de tidslige aspekter af tilværelsen, når de konstrueres omkring et narrativ - døgnet er en fortælling, årets gang er en fortælling, den livshistorie, vi hver især opbygger om vores tilværelse, er med alle dens op- og nedture en konstrueret sammen- 
hængende fortælling, som selv er vævet ind i historiens store fortælling. Vores individuelle fortællinger er struktureret omkring fælles, kulturbårne fortællinger - fortællingen om fædrelandet, om kærlighed, om fællesskaber, om fjendskaber, om sammenhæng og splittelse. Som litteraturteoretikeren Hans Hauge formulerer det „Vi besidder tilsyneladende ikke et ikke-narrativt sprog, hvormed vi kan prise, fremme, støtte, elske, behandle, omtale, forstå, forklare, kritisere fortællingen. Den er et fængsel (...) Vi er i fortællingens vold. Uden den kan vi ikke engang få en identitet og dermed ikke komme ind i landet. Et pas bygger på en national fortælling“ (Hauge, 2000: 7).

\section{Postmodernitet og modfortælling}

Guds død. Relativisme. Fragmentering. Kært barn har mange navne, og alle tre formuleringer er udtryk for samme erfaring: De "store fortællingers“ sammenbrud. En grundlæggende del af (post)modernitetserfaringen - som formuleret i Lyotard: „La condition postmoderne “ - består i, at de store, fælles fortællinger er døde, eller i hvert fald blevet relativiseret. De forløsende grundfortællinger og kerneinstitutioner i den vestlige kulturs selvforståelse som kristendom, oplysning og fremskridt anses i dag bl.a. affødt af verdenskrigene - for at være brudt sammen som fælles, urokkelige referencerammer.

De større rammefortællingers sammenbrud har i stedet givet plads til postmodernitetens mangfoldige udbud af fortællinger og roller, og i et kulturelt globaliseringsperspektiv er det yderligere givet, at en række fortællinger må eksistere side om side. Individet er dog ikke altid selv herre over, hvilke af disse hun tildeles. Og uanset fragmenteringen og individualiseringen bygger ethvert fællesskab fortsat på fælles fortællinger - for eksempel de kanoniserede danske fortællinger om velfærd, grundtvigianisme, bøgeskov og sammenhold trods modgang. Fortællinger indfælder os i sociale, kulturelle sammenhænge, og vores identitet skabes altid i et samspil med en fælles kulturel forforståelse. Vi er kort sagt „blevet fortalt i tredjepersonsfortællinger, før vi påbegynder vores egne fortællinger" (Horsdal, 2000: 130).

Inden for den pædagogiske tænkning har narrativitetsaspektet derfor længe spillet en stor rolle. Den amerikanske filosofiprofes- 
sor og pædagogiske tænker Hilde Lindemann Nelson skriver om, hvordan identitet er narrativt konstrueret og derfor kan rekonstrueres med nye „modfortællinger“. Svaret på en grundlæggende anomi eller manglende plads i de dominerende fortællinger (f.eks. i et samfund) kan være, at man skaber sine egne fortællinger. Magasinerne, som er genstand for min analyse, kan netop siges at udgøre sådanne modfortællinger mod de fælles danske fortællinger, som mange nydanskere angiveligt mener ikke kan udgøre hele deres personlige, kulturelle fortælling.

\section{Journalisten som historiefortæller}

Mens pressen i sin egen selvforståelse helst vil tilhøre de faktuelle genrer, kan der ikke være tvivl om, at journalister dagligt gør brug af fortællingens/fiktionens virkemidler, når de ud af en evig, konstant cyklus af begivenheder og udtalelser konstruerer artikler som sammenhængende fortællinger med indledning, aktører, motiver og konklusioner. Journalistikkens tilbagevendende mantra "don't tell it, show it“ er i sig selv er et paradoks, en teknisk umulighed, idet den trykte presse formidler verden gennem skrift. Pressens enorme samfundsmæssige betydning taget i betragtning står det klart, at netop de journalistiske fortællinger er særdeles vigtige og indflydelsesrige i samfundet. Meget interessant kan skrives (og er skrevet) om omnibuspressens fortællinger om den multikulturelle virkelighed og de etniske minoriteter. Mit fokus ligger imidlertid andetsteds.

Ethvert medie er selv bærer af en historie og et sæt grundfortællinger, og historisk set er nye medier netop opstået ud fra intentioner om at repræsentere et nyt sæt fortællinger. Derfor finder jeg det oplagt at slå ned på netop disse led i aktionskæden (Bro, 2004) - holdnings- og publikationsdelen - og lægge fokus på livsstilsmagasiner, som på den ene eller anden måde specifikt forholder sig til den multikulturelle virkelighed. Endnu har ingen nemlig kombineret teorierne om modfortællinger og narrativ identitetsdannelse med en journalistisk opmærksomhed rettet mod disse publikationer. Dette forsøges der hermed rettet op på. 


\section{Metode}

Döner Magazine er udkommet fire gange, og efter en længere udgivelsespause er nummer fem nu på vej i form af en DVD-udgivelse. Det første nummer har vist sig umuligt at fremskaffe, da det Kongelige Biblioteks eksemplar var bortkommet, og mit empiriske materiale består derfor af numrene 2, 3 og 4. For at give materialet lige vægt og sikre det bedst mulige sammenligningsgrundlag har jeg udvalgt tre numre af Djembe, som tilnærmelsesvis er udkommet i samme tidsrum som numrene af Döner.

For at sikre et konkret og gennemskueligt sammenligningsgrundlag for de to magasiner har jeg kondenseret narrativitetstænkernes teorier ned til fire konkrete parametre/karakteristika ved identitetsskabende narrativer, som vil ligge til grund for den komparative analyse:

1) „Masterfortællingen“ om gruppens identitet, dvs. de væsentligste konstituerende kulturelle karakteristika ved fællesskabet (Nelson, 2002: 13off) præsenteret som sammenhængende narrativ struktur.

2) Forskellene til det øvrige samfund og individer uden for gruppen.

3) Brugen af personae. Personaebegrebet knytter sig til Nisbett og Ross' teori om „repræsentativ heuristik“, og kan beskrives som standardfigurer eller personklichéer, der bruges som led i en større fortælling (den vise gamle kineser, den sadistiske overlærer, den følsomme digter osv.).

4) Genrevalget. Konstrueres den identitetsskabende fortælling som en tragedie, en dannelsesroman, et helteepos, en komedie, et eventyr, en blandingsform eller noget helt andet?

Disse fire parametre er formuleret med baggrund i Paul Riceour (1983): „Temps et recit“, Hilde Lindemann Nelson (2002): „Narrativ oprejsning - når identiteten går i stykker“ og Jerome Bruner (2003): „Uddannelseskulturen“. 


\section{Analyse}

\section{1. „Masterfortællingen“ om gruppens identitet}

\section{En og en er tre - Djembes masterfortælling}

Allerede omslaget på kulturmagasinet Djembe antyder kerneelementer af dets masterfortælling om de etniske minoriteter. Som titel er udvalgt et mundret ord, der let lader sig læse, stave og udtale på dansk, og som samtidig betegner en populær afrikansk tromme. Forsiderne prydes af stiliserede fotografier af eksotiske mænd og kvinder i færd med at danse, synge, spille eller meditere, og i nederste højre hjørne står det korte og præcise programskrift: „Inspiration mellem kulturer“.

Kodeordet i Djembes masterfortælling er „berigelse“. Magasinets stof er primært struktureret omkring det kulturelle/musikalske aspekt af mødet med indvandrernes kulturer, og fokus ligger på den berigelse af modtagerkulturen, som det multikulturelle islæt repræsenterer. Redaktionen vil kort sagt holde læserne opdateret om begivenheder på „hjemmefronten i den flerkulturelle smeltedigel“" (nr.45 s.6). Globalisering er i Djembes udgave et plusord, en betegnelse for den tendens, at verdens folk tager hinandens skikke til sig. „Alt sammen er små brikker i en verdensmusikalsk mosaik, som år for år vokser sig større og større herhjemme (...) Det spirer og blomstrer i dette felt af verdens kulturer"(nr.51 s.4), som lederskribenten formulerer det. Konteksten er overvejende dansk, men det journalistiske udsyn er globalt. Side om side findes artikler om nepalesere, der lærer salsa af en ecuadorianer, om brugen af tibetanske syngeskåle i moderne japansk fusionsmusik og om reggaeboomet i Tyskland.

Kulturmødet sker i form af tilvalg. Om danskere, der tager den tibetanske buddhisme til sig, hedder det „De søger en åndelig oplevelse af den slags, der ikke betyder, at de bliver nødt til at forsage deres egen kulturarv“ (nr.45 s.13), og heri består et kerneelement i Djembes journalistiske modfortælling: Multikultur er ikke et spørgsmål om enten/eller, men om både/og. En pakistansk journalist skriver i en artikel om sin minoritet: „Pakistanere er ambitiøse, veluddannede og fremtidsorienterede. De ønsker at være en del af den danske kultur, og samtidig ønsker de, at bringe deres værdier, traditioner og kulturelle rødder med ind i sam- 
fundet. (...) Det er kun et spørgsmål om tid, før de pakistanske kulturelle rødder finder fæste i den danske muld“ (nr.45 s.24).

Udvekslingen er altså ikke ensidig. Som værtsland er Danmark ikke blot en passiv modtager af fremmed kultur, tværtimod bygger modfortællingen på, at de fremmede inspirationer indsluses i den danske kultur og danner en særlig blandingsform. Om en dansk sambaskole hedder det derfor "selv om vi henter vores inspiration fra Brasilien, fornægter vi ikke, at vi er en dansk sambaskole (...) Vi [gør] ikke tingene fordi ‘sådan gør man i Brasilien', men fordi de giver mening for os og vores måde at holde karneval på“ (nr.48 s.8).

\section{Den stolte perker - Döners masterfortælling}

Döners optik er en anden end Djembes, idet fokus definitivt er flyttet fra modtagerkulturen til indvandreren selv. Journalisterne konstruerer i magasinets masterfortælling deres helt egen hybrid af amerikansk hiphopkultur, mellemøstlige æresbegreber og ærkedansk selvironi. „En kulturel og sproglig blandingskultur, der blandt andet fremgår af den udbredte brug af etnolekter, det vil sige minoritetsgruppers blandingssprog kendetegnet ved inddragelse af ord og vendinger fra deres modersmål. Eksemplerne findes fra amerikaniseringen i bladets undertitel „Til nye danskere med attitude" og de tilbagevendende arabiske ord og vendinger som „inshalla“, der optræder midt i de ellers dansksprogede artikler, til kombinationer som artiklen „Million Dirham Baby“ om en kvindelig morokkansk/dansk bokser.

Tonen er indforstået, og gruppens indre fællesskab og sammenhold betones. Den dansk-algeriske tidligere Guantanamofange Slimane Abderrahmane omtales ved fornavn i lederen: ,Jeg gider faktisk ikke skrive en leder om Slimane - han kan maile os når han er klar til at snakke“ (nr.2 s.5). Selvagtelse og respekt er nøgleord. Senere i samme leder harcelerer chefredaktøren Ali Mohamad over firmaer, der ikke vil annoncere i magasinet: „Det synes jeg, rent ud sagt, er fucked up. Tror de at udlændinge er fattige, eller hvad? Den slags annoncører er håbløst gammeldags, og det er på tide de finder ud af, at der er sat en ny spand kaffe over“. Ideen om den tilbagestående indvandrer er med andre ord håbløst forældet, en ny generation af nydanskere er en del af nutiden 
og fremtiden, og de står ikke tilbage for det øvrige samfund, hverken kulturelt eller finansielt.

I det fast tilbagevendende indslag „Udlændingestyrelsen“ opbygges den kulturelle masterfortælling gennem længere lister over ,in og out-fænomener" formuleret med de islamiske termer „halal“ og „haram“. Jaguar, Alfa Romeo, Red Light District, det spanske sprog, Windows, golfspillet, Mogens Lykketoft og Søren Poppe (!) er således halal, mens Bendt Bendtsens dialekt, mentholsmøger, tysk mad, Krøniken, tyrkiske film (som „altid ender med, at alle bliver skudt i smadder"), og udlændinge, som ikke kan holde styr på deres små brødre, er haram. På- og forbuddene udarbejdes af et større korps af „smagsdommere“ blandt „unge 2.g'ere" over hele landet, som ofte er indbyrdes uenige, og er altså knapt så autoritative som kategoribetegnelserne kunne antyde. Netop titlen „Udlændingestyrelsen“ synes desuden at tilkendegive en dialog med det omgivende samfunds masterfortælling et raffineret ordspil, som på én gang refererer til de danske institutioner og konstituerer de særegent nydanske fortællinger. Ambivalensen og multiperspektiviteten i begreberne er en del af magasinets identitetsskabende journalistiske fortælling. Disse karakteristika gør sig også gældende, når bladet beskæftiger sig med de traditionelle konflikthistorier om indvandrere. Döner lægger sider til artikler om „perkerrockerne“ i Black Cobra-banden, bosniske guerillasoldater og en dansk-pakistaner, som har været i jihad-træningslejr i Pakistan. Tonen i disse artikler er imidlertid langt mere neutral end i de etablerede medier. Terror og kriminalitet forherliges ikke, men forsværges på den anden side heller ikke. I journalistiske termer „vinkles“ der ganske enkelt anderledes, og fokus ligger således primært på, hvad der driver indvandrerne til de pågældende gerninger.

Döner trækker veksler på afroamerikansk ungdomskultur både i attitude, sprogbrug og stilklichéer - „Hip hop blev en vigtig kultur i Avedøre, fordi vi kunne spejle os i den. Ligesom afroamerikanerne og the latinos $i$ The Bronx var vi ikke vokset op med guld og grønne skove, men det bremsede os ikke," siger rapperen Majid (nr.2 s.24). Således er der også blevet plads til billedserier med udfordrende sorte kvinder/ „hos“ - dog ikke mere afklædte end at det forbliver stuerent. Hiphopinspirationen præsenteres 
som en art katalysator i navigationen mellem to kulturer: „Tricket var ikke at blive klemt mellem to kulturer, men at flyde ovenpå - $\mathrm{i}$ det her tilfælde ved hjælp af en tredje - nemlig hiphopkulturen“ (nr.3 s.6). Endnu et vigtigt element i masterfortællingen knytter sig til gadekulturen og den amerikanske inspiration, nemlig det, at nydanskerne var dem, der ,gav gaden stil“, som rapperen Ataf formulerer det (Ibid s.36).

\section{Forskellene til det øvrige samfund}

\section{Den grænseløse smeltedigel}

Når Djembe i den tidligere citerede artikel karakteriserer det multikulturelle Danmark som „en smeltedigel“, rummer det to elementer: Dels den heterogene kulturelle sammensætning, dels den vedvarende udveksling og interaktion mellem kulturerne. Forskellene mellem grupperne er med andre ord vigtige, men i positiv forstand. Bela Bartok-citatet „At ville beskytte sig mod al fremmed påvirkning er som at gå tilbage i tiden; at assimilere disse påvirkninger er at skabe nye muligheder for uendelig rigdom" er ikke overraskende bladets motto.

I en artikel om det pakistanske mindretal i Danmark formuleres det særdeles klart: „Da jeg kom til Danmark i 1969, var det eneste krydrede måltid, du kunne få i København, kinesisk kylling med sojasauce (...) og det mest eksotiske krydderi var sort peber“ (nr.45 s.22). Forskellene er til stede, men som berigende og positive elementer. De danske kvinder er blevet inspireret af pakistanernes farvestrålende tøj, pakistanere har fyldt hullerne ud på det danske cricketlandshold, og pakistanske sportsfolk har hentet guldmedaljer til Danmark i karate, taekwondo og judo.

Grundlæggende er artiklerne i Djembe altså kendetegnet ved et markant fravær af skillelinier i form af negative grænser. Forskellene mellem minoriteterne og danskerne, og mellem forskellige kulturer i det hele taget, er inspirationskilder og ikke ukrydselige grænser. I en artikel om perspektiverne i globalt samarbejde mellem kunstnere hedder det: „Det er på tide at komme bort fra den mentalitet, der lå bag datidens verdensudstillinger, hvor man udstillede etniske grupper som seværdigheder. Vi skal begynde at se verden og dens kunst som en helhed“ (nr.45 s. 30). 


\section{Stuck in the middle}

Döners skildring af kulturmødet er knapt så romantisk og problemfri. Döners nydansker er udmærket klar over, at han skiller sig ud fra det øvrige danske samfund. „Du er perker, og du må lære at leve med det,“ (nr.3 s.4) formulerer musikproduceren Atilla Dogan det i et interview. Der skelnes imidlertid også internt i gruppen mellem nydanskerne ud fra deres oprindelseslande. Det er væsentligt, om man er pakistaner, iraner, tyrkisk kurder osv., og der knytter sig særlige karakteristika til hver undergruppe (bl.a. er de iranske piger efter sigende løse på tråden). Visse steder bruges ordet dansker som det modsatte af nydansker, andre gange betegner indvandrerne i bladet sig selv som danskere (jævnfør formuleringen „Du er den første hvide dansker i Döner“ i nr.2 s. 35).

En del af forholdet til det øvrige samfund er præget af mødet med fordomme. Således bilentusiasten Faraz Ahmed: „Er du blevet standset af politiet i din bil? Ja, jeg har desværre et nært forhold til dem. Chikane hører med til gamet“ (nr.2 s.33), redaktøren Nagieb Khajas forhold til de etablerede medier: „For os 'brune' er det foruroligende, at tilliden til medierne er så stor“ (nr.4 s.3) og musikproduceren Atilla Dogan: „Jeg behøver jo bare at stige ind i et S-tog eller en bus for at mærke de der blikke. De fleste danskere over 50 år ved så utroligt lidt om udlændinge, og så bliver de usikre“. Sidstnævnte fortsætter dog „Det gælder egentlig også den ældre generation af udlændinge i Danmark - de ved måske endda endnu mindre om danskerne" (nr.3 s.6). Midt imellem disse to generationer sidder Döners nydansker, som hverken inkarnerer sine forældres eller den danske kultur, men noget helt tredje. Denne mellemposition kommer også til udtryk i en kvindelig klummeskribents harceleren over indvandrerpiger med en fjendtlig indstilling til Danmark: "If u wanna be kool, then u don't have to be danish or no perk ... U gotta be stuck in the middle, and be a part of both u jerk" (nr.4 s.65). Samme identitetsfortælling kommer til udtryk i et interview med musikproduceren Atilla Dogan: ,Jeg synes der er for mange, der går rundt kun med sig selv eller med hinanden uden overhovedet at gide sætte sig ind i danskernes normer og traditioner. For mig har det været vigtigt både 
at holde fast i den kultur jeg har fra mine forældre, men samtidigt også at sætte mig ind i kulturen der hvor jeg lever" (nr.3 s.6).

Den journalistiske identitetsfortælling opbygges således raffineret: Indvandreridentiteten består ikke i at være fuldblods-pakistaner, palæstinenser, tyrker osv., men netop i at befinde sig i grænselandet mellem forældrenes kultur og den danske. Afstanden til det omgivende samfund er med andre ord ikke det eneste konstituerende karakteristikum ved gruppens identitet, ligheden betones også. Forholdet imellem ligheden og forskellen er imidlertid til tilbagevendende diskussion. Symptomatisk er de medvirkende kilders temmelig ambivalente forhold til hunde. Nogle steder i bladet hyldes kamphundekulturen, fascinationen af ,en wicked lille vovse" (nr.2 s.12), mens en skribent andetsteds forarges over indvandrere, der har svigtet deres egen kultur ved at se igennem fingre med, at hunden ifølge mellemøstlig tradition er et urent dyr: „Perkere der har hund (what da fuck). Din farfar kunne ikke lide hunde, din far kan ikke lide hunde. Hvad fanden gik der galt for dig, perker?“ (nr.4 S.41).

Döners journalister betoner altså forskellene og skillelinierne mellem de nye og de gamle danskere, men dyrker også det morsomme ved sammenfald mellem det omgivende samfunds fælleskulturelle masterfortællinger og gruppens egen selvforståelse. Således det humoristisk anlagte interview med indvandreren, der hedder Flemming, og som har sjov ud af at ringe til offentlige myndigheder, som ikke kan høre, at han er indvandrer. „Nogle gange har jeg hørt på, at folk har talt grimt om udlændinge til mig fordi de ikke vidste, at de snakkede med en udlænding, og jeg lader bare som ingenting. Det er meget sjovt" (nr.2 s.6). Identiteten som udlænding og de religiøse værdier står dog ikke til diskussion: „hvis man er muslim, skal man hedde noget muslimsk (...) man skal ikke slette hele sit gamle navn, for eksempel fra Muhamed Mustafa til Lars Jensen, det synes jeg er forkert. Det handler om hvilken slags moral man har" (do), afsluttes interviewet.

Et enkelt sted kammer en skribent over og går i „Udlændingestyrelsen“ til frontalangreb på Naser Khader, jøder, homoseksuelle og indvandrere der stemmer ved valgene og i øvrigt gider at lære dansk, mens han forsvarer Osama Bin Laden og jubler over tsunamien (nr.4 s.35-42). Om der er tale om dårligt leveret ironi er 
svært at afgøre, men indlægget skiller sig voldsomt ud fra bladets øvrige journalistiske fortællinger ved at understøtte en eksisterende, negativ fortælling frem for at skabe modfortællinger.

\section{Brugen af personae/personklichéer}

\section{Provinsiel eller progressiv?}

Djembes journalister kredser ofte om en tilbagevendende figur, nemlig den velintegrerede indvandrer med et ben solidt placeret i hver sin kultur, som netop i kraft af dobbeltperspektivet kan give et unikt kulturelt bidrag til værtskulturen. Bassisten Moussa Diallo ,har et ben i begge traditioner: Hans mor er dansker, hans far er malier (...) Han har søgt og udforsket sine rødder - både menneskeligt og kunstnerisk“ (nr.48 s.6), og i et interview med den indisk-danske sanger Navtej Singh Rehal hedder det „Måske har du lagt mærke til, at Danmark for nylig har fået sin egen Panjabi MC? (...) Han taler flydende panjabi og dansk. Navtej [forsøger] at skabe en symbiose mellem bhangra og nogle af Vestens mange musikalske udtryk og fokuserer på, at nøgleelementerne i de forskellige stilarter bliver bevaret“ (nr.45 s.19). Fælles for de portrætterede indvandrere er dels deres vægtige bidrag til det kulturelle udbud i samfundet, dels deres manøvredygtighed i feltet mellem to kulturer. Mødet mellem kulturerne er, både for dem selv og for samfundet som hele, et plus.

Mens indvandrerne således i høj grad tegnes gennem positive klichéfigurer, tegnes de danske modtagere af fremmed input mindre karikeret. Magasinets journalister ironiserer selv over new age/halalhippie-mentaliteten, som man måske kunne beskylde dem for at ligge under for, og lægger afstand til 68-generationen. Således formuleringen „'Trods fattigdom er det indiske folk de mest lykkelige mennesker, jeg nogensinde har mødt,' udtaler den canadiske maler (...). Hvor lotus-spisende dette end lyder, så er moderne buddhistrejsende ikke som tidligere hippiebackpackers“ (Ibid s. 14). Enkelte steder gøres der dog brug af personklichéer i billedet af danskerne. I artiklen „Provinsielle Danmark uden reggae" forklares danskernes manglende interesse for det ellers fælleseuropæiske reggaeboom med vores „alt for forsigtige - nærmest luskede“ musiksmag. „Det danske publi- 
kum er ganske enkelt mindre nysgerrigt. Danskerne er sig selv nok, “ (nr.48 s.18) citeres en svensk pladeselskabsmand for. Djembe benytter altså personae som modfortælling i dobbelt forstand. Både gennem klichéen om den ressourcestærke, multiperspektiviske indvandrer og gennem klichéen om den skeptiske, træge dansker.

\section{Hundekamp og gangsterattitude}

Döner-journalisternes brug af personae er langt mere drastisk, idet selve bladets narrative projekt er funderet på en basis af hævdvundne klichéer om nydanskeren: Han praktiserer ulovlig hundekamp, elsker store biler, har en ikke helt sund interesse for knive, er fascineret af gangstermiljøer, har let ved at score lyshårede danske piger og er i øvrigt småkriminel. Allerede med titlen Döner befinder vi os i hjertet af en gængs indvandrerkliché: Shawarmabaren - med en potentielt sjofel undertone, hvis man lader freudianismen få plads og gør shawarmarullen til et fallossymbol. Klichéerne går igen på alle områder - computerspil anmeldes med en til fem arabiske krumsabler, og blandt artiklerne findes en anmeldes af en khat-klub for somaliske mænd.

Til de længere interview castes nydanskere, som på den ene eller anden måde inkarnerer klichébillederne. På de tilhørende fotografier poserer de som afroamerikanske ghettorappere foran sportsvogne med brede fælge og guccisæder. Uniformen er den samme: kasketter, guldsmykker, hættetrøjer og et sammenbidt ansigtsudtryk. Selvironien får dog også en plads, idet vinklingen flere steder også lægger distance til klichéerne og gangsterkulturen. Som når rapperen Majid konstaterer ,Jeg kan ikke stå og sige at jeg er gangster, når jeg ikke er gangster. Jeg er en pædagogmedhjælper, og det står jeg 100 procent inde for“ (nr.2 s.18). Flere steder forekommer et sådant glimt i øjet, bl.a. i omtalen af en københavnsk våbenbutik, der har et såkaldt ninja-anker i varesortimentet: „Du står uden for et diskotek, og den bredskuldrede dørmand kigger på dine spritnye Nike-sneakers, dit sorte hår og din brune teint og ryster bestemt på hovedet, og nægter at lukke dig ind. Hvad gør du så? Du lusker rundt om hjørnet, folder dit medbragte ninja-anker ud, kaster det over muren og klatrer lynhurtigt ind i baggården til diskoteket“ (Ibid s. 28). 
Også billedet af gammeldanskere er bygget op omkring personae. Danmark omtales konsekvent som „kartoffelland“, og de hvide danskerne ganske enkelt som „kartofler“. I et interview med en dansk politibetjent, som er fotograferet med cowboyhat og sherifstjerne, hedder det "han kan buste dig i en grad, som du aldrig er blevet bustet før" (nr.4 s.11). Med denne ene sætning konstruerer journalisten to personklichéer: Den kriminelle indvandrer og den afstumpede danske politibetjent, som helst ville have været cowboy. Karikaturen af sidstnævnte underbygges videre af interviewstumper som ,jeg er glødende tilhænger af den militære indsats i Mellemøsten“ og ,mange af dem [de kriminelle indvandrere] trænger til at tage niende klasse om fire gange“.

Frem for at afskrive den potentielt fordømmende fortælling om indvandrere som en anderledes gruppe i det danske samfund, går magasinets journalister altså i dialog med fortællingen og videreudvikler den på dens egne præmisser.

\section{Genrevalget}

Djembes journalistiske fortælling om de etniske minoriteter i Danmark er så afgjort et eventyr. Indvandreren er helten, der med sin magiske tromme har vundet prinsessen, det halve kongerige og den taknemmelige befolkning, som vil leve lykkeligt til dens dages ende i en fornyet verden af multikulturelle sansebombardementer. Helt centralt i denne modhistorie står dyrkelsen af det rige udbud af kulturelle input, som den kulturelle globalisering og migrationen har muliggjort. Tiden, hvor sort peber var det mest eksotiske krydderi, og hvor salsa, gnawa, djembe og tandoori var ukendte ord for den brede befolkning, var i bund og grund småkedelig, og forskellene mellem nye og gamle danskere er blot en kilde til inspiration. At tilhøre flere kulturer - eller blot få lejlighed til at møde dem - er i Djembes journalistiske optik et privilegium. I vejen står kun eventuelt snæversyn eller manglende nysgerrighed og vilje til at tage del i den nyfundne krydrede virkelighed.

Döners masterfortælling minder til gengæld mest af alt om en dannelsesroman. Fortællingens helt, „nydanskeren med attitude“, er draget hjemmefra, har forladt sit oprindelige udgangs- 
punkt, og må gå grueligt meget igennem, før han kan indtage sin velfortjente plads i samfundet og dets overordnede masterfortælling. En del af selvforståelsen bygger nemlig på erfaringen om at være forfulgt. De tragiske elementer overskygges dog langt af de tilbagevendende elementer af helteepos og komedie. Indvandreren er i Döners optik den selvsikre, stilfulde outsider med glimt i øjet, der kører i dyre biler og snupper kartoflernes piger.

\section{Konklusion}

Som nævnt indledningsvis er der vægtige argumenter for at betragte fortællingen som et centralt begreb i forståelsen af den menneskelige begrebsverden. Ethvert samfund bygger på et større kompleks af eksplicitte og implicitte fortællinger - samt en stor portion interaktion mellem disse. De eksplicitte journalistiske fortællinger, der fremsættes i nichemedier som Djembe og Döner, kan have relevans for de implicitte fortællinger om identitet, grupperinger og forskelle i Danmark. Samfundets underliggende fortællinger og personae ændres næppe drastisk som følge af modfortællinger fremsat i to livsstilsmagasiner med lavt oplagstal (og i Döners tilfælde en noget ustabil udgivelsesfrekvens). Ikke desto mindre har nærværende analyse udpeget og sammenlignet to bud på en identitetsskabende fortælling om de etniske minoriteter i samfundet, to journalistiske strategier til at sikre mindretallet en plads i flertallets dominerende fortællinger.

Hvor Djembes masterfortælling bygger på berigende kulturel globalisering og kulturudveksling som et tilvalg, opbygger Döner en indforstået masterfortælling om indvandreren som en eksklusiv, selvbevidst og ambivalent figur. Hos Djembe er forskelle alene et positivt element, som fører til inspiration og berigelse. Döners indvandrer er til gengæld kendetegnet ved et mere problematisk forhold til det omgivende samfund. Han ved, at han er anderledes end kartoffeldanskeren og er derfor vant til at møde fordomme. Forskellen er imidlertid dobbelt, da han også skiller sig markant ud fra sine forældres kultur og dermed inkarnerer en særegen tredje position - og gør det med stolthed. Mht. brugen af personae er Djembe kendetegnet ved sin favoritfortælling om den velintegrerede indvandrer med en værdifuld dobbeltoptik, 
som kan veksles til unikke kulturelle bidrag til samfundet. Döner går mere drastisk til værks og leverer et helhjertet forsøg på at skabe en raffineret ny personkliché, en positiv modfortælling om en eksklusiv indvandreridentitet. Sammenlagt ender vi med to kreative bud på en journalistisk fortælling om det multikulturelle samfund: Eventyret om den kulørte globaliserings velsignelse og dannelsesromanen om den stolte perker.

Mange initiativer bliver disse år taget i retning af at inkorporere nye danskere i den fælles danske fortælling. Også journalister kan levere et interessant supplement til disse bestræbelser gennem en øget opmærksomhed rettet mod narratologien og dens grundlæggende tese om, at historie skabes aktivt. Det er os selv, der påtvinger fortiden en sammenhæng og dermed forvandler den til historie, og lige sådan forholder det sig med nutiden. Køber man den grundlæggende præmis, at identitet konstrueres aktivt og løbende, kan en aktiv strategi om modfortællinger være af stor betydning, når en fortællings dele og dens helhed skal bringes til at udgøre én hel fortælling.

Som min analyse har påvist, er der flere måder at konstruere en identitetsskabende journalistisk fortælling på. Om man finder Djembes jublende berigelsesfortælling eller Döners eksklusive subkulturdyrkelse mest formålstjenstlig er i sidste ende et spørgsmål om personlige præferencer og politisk overbevisning. Ikke desto mindre er en bevidst brug af narrativets identitetsskabende muligheder en oplagt strategi, hvis journalister skal få fortællingen om højskoler, kebab, bøgeskov og samba til at hænge sammen.

\section{REFEREN CER}

Bro, Peter (2004). Aktionsjournalistik - historie, holdning og håndvark, Odense: Syddansk Universitetsforlag.

Bruner, Jerome S. (1987). “Life as narrative”, Social Research, vol. 54, nr.1. Bruner, Jerome S. (2003). Uddannelseskulturen, København: Hans Reitzels forlag.

„Djembe - inspiration mellem kulturer“ nr. 45 (august-september 2003), 48 (april-juni 2004) og 51 (januar-marts 2005). 
„Döner Magazine - til nye danskere med attitude“ nr. 2 (april 2004), 3 (februar 2005) og 4 (september 2005).

Halse, Svend (red.) (2004). Livet som indsats - livshistoriske satsninger og iscenescettelser, Odense: Syddansk Universitetsforlag.

Hauge, Hans (2000). „Fortællingens genkomst“, Kvan, 20. årgang, nr. 58, pp. 7-21.

Hermansen, Mads og Rendtorff, Jacob Dahl (red.) (2002). En hermeneutisk brobygger - tekster af Paul Riceour, Århus: Klim.

Horsdal, Marianne (2000). „Livets fortællinger“, Kvan, 20. årgang, nr. 58 pp. 126-135.

Kemp, Peter (1999). Tid og fortcelling - introduktion til Paul Ricoeur, Århus: Aarhus Universitetsforlag.

Lyotard, Jean-Francois (1979). La condition postmoderne: Rapport sur le savoir, Paris: Editions de Minuit.

Nelson, Hilde Lindemann (2002). Narrativ oprejsning - når identiteten går $i$ stykker, København: Gyldendal.

Nisbett, Richard E. og Ross, Lee (1980). Human inference; Strategies and shortcomings of social judgement New Jersey: Prentice Hall.

Riceour, Paul (1983). Time and Narrative I-III, Chicago: The University of Chicago Press. 